\title{
Research on Metrology Museum Culture and Its Creative Industry
}

\author{
Lanying, Guo, Yunyou Sun \\ College of Humanities and Foreign Languages, China Jiliang University, Hangzhou, China \\ Security Department, China Jiliang University, China Jiliang University, Hangzhou, China \\ gly@cjlu.edu.cn, syy_1126@163.com
}

\section{Keywords: Metrology Museum, Culture product, Cultural Creative Industries}

\begin{abstract}
Metrology Museum located in China Jiliang University takes both culture and creativity as the key elements of industry connotation in its development. It functions more socially and publicly in the diversified cultural services in integration. Therefore, with the profound demands of cultural creativity on the expansive industrial structure, Metrology Museum is inevitably included in the development of cultural and creative industries. This paper makes a detailed analysis on Metrology Museum culture focusing on its spatial functions as a display platform to record the historical changes, an academic institution to represent the academic and cultural accumulation of the university, an art performing stage to inherit metrological culture, a tourism site to attract the world attention and a spiritual and cultural home to excite metrology fans.
\end{abstract}

\section{Introduction}

"The value proposition of museum highlights gradually the inclusion, participation and integration of social development since the beginning of its service of both society and value concept" (Wang, 2016). In the long history of human evolution and social progress, museum culture plays an indelible role in its innovated function of collection, reservation, display, exhibition, research and representation of the natural and human cultural heritage. Not only the provision of knowledge, education and appreciation of cultural education institutions, buildings, places or social public institutions has embodied the positive scientific, historical or artistic value, but also the creativity of ideas, arts, skills, products has fostered the cultural advancement in industrial domain supported by a turning from "collections" into "commodities" in a combination of creative thought and market demand. In the aspect of cultural and creative development, such new strategies, ranging from the design of derivative products to the reformation of sales platform, have motivated the static cultural relics to generate the vitality drawn from the modern design and the "new retail" consumption. From this perspective, cultural and creative development has become a good "business" for cross-culture communication as well.

\section{Metrology Museum Supported by Policies}

Museum cultural and creative development has been promoted in the international scale since the foundation of International Council of Museum (ICOM) in Paris in November 1946. After the declaration of May 18, 1977 as the first international museum day, ICOM determined the theme for the International Museum Day each year concentrating on historical collection, universal heritage, cultural property protection, incorporeal hereditament, etc. at the early years to follow up the general function of museum culture. Then ICOM shifted the themes from static to more dynamic topics for the subjective involvement to draw attention of responsibility, adaptation and professional ethics of the creator and disseminator of diversified culture. The recent themes touched the even broader relationship with environment, pleasure of discovery, building community, globalization, friendship, intercultural communication, the young, social peace and harmony, social change, sustainable development and reform, tourism, cultural landscapes, new approaches and new publics. The theme, entitled as "Museums as Cultural Hubs: The future of tradition" delivered in the Museum Day in 2019, has provided museum culture with more opportunities in its connection with 
creative industry.

"To follow the scientific principles and to improve the policy system for the cultural industry" (Song, 2019) suggested by the scholars demonstrate the significance of policy support in the cultural creativity. In China, governmental support in policy has boosted a great step forward towards the advancement of museum cultural creative industry in terms of standardization and legalization. Regulations on Museum enacted officially on March 20th, 2015 has engendered a remarkable trans-formation of the museum sector to encourage museums to engage in business activities, explore the connotation of collections, and integrate with cultural creativity, tourism and other industries. In May, 2016, Several Opinions on Promoting the Development of Cultural and Creative Products by Culture and Cultural Heritage Organizations issued officially by Chinese State Council Gazette further pushed the development of cultural and creative industries into the "fast lane" to boom museum cultural and creative industry. Taken the advantages of this opportunity, university museums have speeded up the exploration and practices of cultural and creative industries to transmit more culture and popularize more scientific knowledge.

"To activate cultural relics is the shared value of museums and society" (Li, 2015). Under the guidance of Metrology Development Planning (2013-2020) by the State Council Gazette, Metrology Museum opens to welcome the first guests in September 2017 after 4 years construction, functioning professionally in collection, exhibition, research, education, cultural exchange, integration, popularization and promotion in metrological orientation. In the teachers words, Metrology Museum "not only explores the mystery of science, interprets the connotation of the discipline, still, it is a perfect place to initiate professional education of the students." (Ma, 2018). In a broader sense, Metrology Museum has highlighted its special features in cultural, creative and market attributes.

\section{The Wonder of Metrology Museum Culture}

"A professional museum adopts its unique professional methods to interpret the historical development of the industrial process and cultural connotation" (Shan, 2011). Defined as a science based on technology and legal means to achieve unity, accuracy and reliability of measurement on the basis of quantity value system, metrology pursues fair and justice, reliability and sincerity as the norms and cultural concept descended from Chinese ancestors. Metrology Museum attracts the public by its perfection linking to planning, brand building, design and development, mass production, marketing promotion, and integration in diversity. It records the human history from the ancient origination, pre-Qin Dynasty, the warring state period of Spring and Autumn, Wei Jin Southern and Northern dynasties, to the modern ages accompanied by its inter-weaved culture and the disciplinary development of China Jiliang University. In length, it is easy to trace the historical and cultural footprints of various metrological pioneers along with the process of germination, formation, evolution, maturation and development in ancient Chinese metrology. In width, it is exciting to appreciate the beautiful arts of the metrological instruments and to experience the essential connotation of ancient Chinese metrology culture as well.

To some extent, Metrology Museum highlights its culture through the important events, the memorable characters and the significant landmarks. More than 1000 exhibits on display tell their stories with the affiliated words, pictures, multimedia, and even experience of interaction. "The great sculpture at the entrance goes through the ancient and modern history. The left recalls the myths and legends of "Fuxi" and a goddess named "Nvwa" in ancient China, holding a ruler and a gauge symbolizing justice and order while the right inspires the applications of metrology in such modern science and technology as telescope, scale, rocket, satellite, etc" (Jia, 2017). The bamboo slips interpret the significant events represented by two measurement instruments of sundials, an instrument to record time according to the reflection of sun shadow, a standard capacity measuring instrument of Xin Mang period during 21 B.C. to 1744 A.D. More than 200 idioms with the attached pictures in terms of length, capacity and weight brighten the ancient traditional heritage into a great wonder. The memorable painting of "Dayu Flood Control" marks both the hero by his legend spreading in China over thousands of years and the standardization of length in measurement. 
The description of pre-Qin Dynasty in texts and pictures help to interpret the specialization in units, instruments, professionals and organizations relating to metrological length, capacity and weight. The vivid scene of the unification of weights and measures by the first Emperor of Qin marvels traditional measurement section in the signification of unification of weights and measures for the purpose of centralization of power and consolidation of rule. The two replicas of Xin Mang copper caliper and sundial gauge in Han dynasty help to witness the advanced metrological testing technology while the map interactive device arouses the human curiosity of space exploration. Metrology Museum culture condenses cultural, historical, scientific, artistic, creative, industrial perspective into the development of metrological history and reflects the educational philosophy of "Metrology as University's Cornerstone, Standards as its Code of Conduct, and Quality as its Career Goal" of China JiLiang University.

\section{The Creativity of Metrology Museum Culture}

"After the 14th National Congress of the Communist Party of China defined the goal of building the socialist market economic system, the market orientation of cultural system reform was gradually clarified in the theoretical contention on culture popularization, cultural marketization and other hot issues" (Chen, 2019). However, the foundation of cultural creative derivative lies in culture with its soul in creative design. A brilliant derivative of cultural creativity perfectly integrates practicality with artistry, technology, conception or even emotion it conveys in a spatial structure. Therefore, cultural creative derivative inside Metrology Museum not only display the 1000 exhibits in the practical objects but convey emotions or resonance in the subjective spiritual demand. The ancient coins donated by Mr. Lin zhiguo tie him closely to ancient Chinese currency and the love of China Jiliang University and also metrology cause. So, it is the mixture of both internal and external creative derivative that strengths Metrology Museum culture powerfully.

As is known, Metrology Museum culture forms a general concept of accumulation in creative ideas supported in multiple dimensions. Campus culture is a major component of Metrology Museum spatial culture. Jialiang Great Hall reproduces an architectural beauty of the artistic style of Xin Mang Jialiang in Han Dynasty. The stone inscription standing in front of the library features the university motto of "Developing National Economy by Metrology; Improving People's Livelihood through Measurement", a creative idea by the former students. More stone figures erecting in the campus have witnessed the activities and progress along its way to the high-quality distinctive university for its metrology, standards, quality, market regulation, inspection and quarantine. Tian Wen science and technology activity center and the buildings of Yang Yi and Fang Yuan have a strong flavor of "metrology" being named in the terms of metrological characters. The roads around the campus are all after the famous talents to memorize their devotion to metrology, such as Chong zhi Road, Shou Jing Road, Zhang Heng Road, etc. The long-standing measurement culture has been further inherited and continued in the modern university campus decorated by the stone scale weight slides separated here and there around campus.

The "movable metrological museum" entitled "The Century of Metrology" has moved the metrology fans since the fascinating performance of the original musical dance epic came onto the stage for the premiere show on Oct. 17, 2018. The cultural feast of the stage performing art originally composed, directed, and performed by more than 70 teachers and students has brought together interdisciplinary teams of experts in literature, history, music, dance, etc. The stage art and audio-visual excellence of 5 brilliant acts and 13 wonderful scenes repeating the significant stories in earlier metrological history, the cosmic symphony of the sun, moon and stars, accompanied by the creative dances of Liu Xin's "li shu dance", Zu Chongzhi's "moonlit dance", Guo Shoujing's "starlight dance" and Xu Guangqi and Matteo Ricci's "geometry dance" have achieved impressive applause and inspired more than 13,000 audience through the live broadcast on mobile phones, and attracted Baidu hot search for three days, secondary only to West Lake University in popularity. The epic has set up a brilliant brand of metrological culture.

"Basic public cultural services not only meet people's cultural needs, but also provide support 
and guarantee for the development of the cultural industry with material and human resources, public facilities, consumption market and other elements for cultural consumption" (Li, 2018). The interaction of Metrology Museum with Jia Liang Science and Technology Park, solidifies both disciplinary and commercial values. Ranking the second National University Science and Technology Park in Zhejiang Province, it has gained its honor of national excellent (Class A) Science and technology business incubator in the assessment in 2018. Hundreds of incubated businesses in the park have succeeded in researches, patents, intellectual properties, brands and products. During the science and technology achievement auction co-organized by Zhejiang Province and China Jiliang University in 2018, more than 30 effective scientific and technological achievements by Jiliang teachers and students were auctioned off at the starting price of 17. 40 million yuan (RMB) and the actual total transaction price of 21.448 million yuan (RMB) with a premium rate of $25.87 \% .39$ companies participated in the auction.

Zhejiang Social Science Popularization Base approved by Zhejiang provincial social science federation authorizes Metrology Museum as an open tourism site to the public. Up to now, it has accepted thousands of tourists since its opening, including governmental leaders, official staffs, scholars, teachers, students, primary school pupils and metrology fans in general. Through the six chapters of formation, unification, theorization, evolution, transformation, and the development of metrological history within two exhibition halls, the visitors experience the cultural evolution, sense the ancient civilizations, taste the beauty of instrumental arts and absorb metrological knowledge. The impressive views written especially in the students and pupils compositions are extremely moving and inspiring since "the display "have glutted their eyes" and the ancient wonder "have flamed their curiosity". The visitors harvest their gifts and souvenirs through the experience of touching the multimedia screen after answering questions and entertaining themselves by games.

\section{The Prospective Market of Metrology Museum Culture}

From the market perspective, a growing trend appears certain in the foreseeable future. However, the way to metrological cultural creative industry is a long progress. A brilliant page of Metrology Museums may go to more introductions to world metrological history following the civilizations of ancient Babylon, Egypt and so on. Intercultural Communication in metrological aspect involving conferences, forums, exchanges of teachers and students, academic collaboration will go into the depth to promote the discipline development and to follow the forefront trend of the metrological world. It is also significant to compare and contrast the similarities and differences of metrology between China and foreign countries. The metrological inventive marvels and devotions of minority nations or groups should be respected and focused on.

The creation of the robot named "Xiao Liang" is going to function as the narrator of Metrology Museum, the actor or actress in "The Century of Metrology" and the perpetual calendar for services. Such competition as mascot design held by CJLU League in 2017 has provided the students with more cultural creative design opportunities. "Liang Liang" had been honored finally as the mascot for CJLU 40 th Anniversary and the other candidates of "Mole", "Siji", "Xiang Xiang" and "Yang Yang", "Dreams", "Mr.Tuan Tuan", "Big White" designed also by the student have attracted many visitors. To extend the tourism market, marketing channel of internet-based can direct consumers to online shopping mall for purchase of the cultural creative commodities. Cost performance has its significance in consideration for the public. With the consideration of the public consumption level, the tourist souvenirs can be diversified ranging from basic needs of several yuan (RMB) to high class necessities of thousand yuan (RMB) to satisfy various visitors. The pioneering thinking in cultural creative design and the redefinition of product attributes with high cost performance are worthy of more detailed study.

\section{Summary}

Metrology Museum has taken an active part in interdisciplinary research on such relations as metrology history and culture, metrology and national governance, metrology and ideology, 
metrology and campus culture, metrology and Party building, metrology and exchange. This paper deals with Metrology Museum culture and its creative industry by the commended chain of Metrology Museum culture, Jia Liang Great Hall, the "movable museum" by stage performing art of The Century of Metrology, Jia liang scientific and technological park and Jiliang university campus as a main line. The fusion of cultural functions in exhibition, collection, education, research, art, performance, research, architecture, tourism, cultural exchange, popularization, etc. has speeded both metrological culture and China Jilaing University as well into highly creative industrialization.

\section{About the Author}

Name: Lanying, Guo, (female)

Title: Professor and MA supervisor in College of Humanities and Foreign Languages in China Jiliang University.

Research area: cross-cultural communication, comparative literature, translation, cultural creative industry.

Mobile Phone: 1385717638515868166380

Fax: $86+571+86914498$

E-Mail: gly@cjlu.edu.cn

Name: Yunyou Sun

Title: A staff responsible for fire prevention and control in Security Department in China Jiliang University.

Research area: Campus culture studies and fire prevention and control

Mobile Phone: 13758199752

Fax: $86+571+86914464$

E-Mail: syy_1126@163.com

\section{Acknowledgment}

This research was financially supported by the National Social Science Foundation of China (Grant NO. 17BWW046).

\section{References}

[1] Xiuwei. Wang, The Research on Museum Cultural Licensing in the Horizon of Cultural Creative Industries, A dissertation for Doctor's degree, University of Science and Technology of China. pp. IV, 2016.

[2] Haidong, Song \& Xuecong, Yang, The Development of American Cultural Industry and Its Enlightenment to China, Modern Business Trade Industry, vol. 29, pp. 42-43, 2019.

[3] Zhengshan. Li, The Significance of the Regulations on Museum and the Future of Museum, China Cultural Heritage Scientific Research, vol.2, pp.1-5,2015.

[4] Yue. Ma, Fengxiao. Li \& Ying. Zhao, University Museum: Elegance out of Boudoir, Zhejiang People's Congress, vol. 6, pp. 56-58,2018.

[5] Zhen, Shan, Hua.Long \& Dong. Wang, The Significance and Strategy of the Establishment of Metrology Museum in China, China Metrology, vol.11, pp.62-64, 2011.

[6] Yuesong. Jia, Spread Metrology Culture and Popularize Metrology Knowledge, China Metrology, vol.11, pp. 80-83, 2017.

[7] Geng. Chen, The Chinese Cultural System Reform in the Past 40 Years: A Theoretical Review, Journal of Shandong University (Philosophy and Social Sciences), vol.5, pp.174-184, 2019. 
[8] Wenjun. Li \& Qiaoming. Li, The Course and Orientation of Development of Cultural Industries over the Past 40 Years of Reform and Opening-up, Reform, vol.12, pp.50-64, 2018. 